\title{
Financial Sustainability Issues in Malaysia's Telecentres
}

\author{
Huda Ibrahim (Coresponding Author) \\ UUM College of Arts and Sciences, Information Technology Building \\ Universiti Utara Malaysia, 06010 UUM Sintok Kedah, Malaysia \\ Tel: 60-1-2207-6142_E-mail :huda753@uum.edu.my \\ Azman Yasin \& Zulkhairi Md Dahalin \\ UUM College of Arts and Sciences, Information Technology Building \\ Universiti Utara Malaysia, 06010 UUM Sintok Kedah, Malaysia \\ Tel: 60-4-928-4701Ｅ-mail: \{yazman|zul\}@uum.edu.my
}

\begin{abstract}
Telecentres plays an important role in bridging digital divide in Malaysia. A study was conducted to identify the issues of financial sustainability on 132 telecentres in Malaysia. The study focused on TCs in four regions of Malaysia Peninsular (northern, central, southern and eastern). Questionnaires were sent to the telecentres' operators. The results prove that financial support is critical in operating and maintaining the centers. The costs incurred in running telecentres involve the costs for promotion, staff, utilities, premise renting, and training. More than 75 percent of the telecentres are operating under tight cash budget. Recommendations are given to encourage telecentre's financial sustainability in the future.
\end{abstract}

Keywords: Telecenter, Sustainability, Financial sustainability, ICT services, Digital divide

\section{Introduction}

Telecentre (TC) is a physical space that provides public access to information and communication technology (ICT) notably the Internet for educational, personal, social, and economic development (Riley \& Gomez, 2001). Telecentre is also referred as a one-stop centre that provides ICT resources to the public access, dissemination of information and knowledge and e-government services, e-banking, e-health and others to improve socio-economic status of targeted local communities (EPU, 2007). The establishment of TC as a multi-purpose community centre is among the initiatives taken to reduce digital gap in Malaysia. These initiatives have been formalized into three major forms: i) top-down model, ii) down-up model, and iii) top-down-up model (UNESCAP, 2006).

Top-down model is launched by the central government. Examples of top-down projects are Pusat Internet Desa (PID), Medan InfoDesa (MID), Universal Service Provision (USP) program, and State government projects. In contrast, down-up model, is a collaboration effort of non-governmental organizations and community-based organizations and government agencies. The projects are mostly funded by a national or international level grant, for instance United Nations and some foreign country's based fund. Examples of down-up model are TaniNet, and e-Pekak. Similar to top-down model, top-down-up model, is also a government project but this model is implemented with a high participation of community. Top-down-up projects include e-WargaKota, Eagle's Net, Warga Emas Network, Pesarajaya, and e-Upcom. By 2009, there is a total of 1169 TCs established under the Universal Service Provision (USP). These TCs, among others include 42 Pusat Internet Desa, 39 Medan InfoDesa, 58 Community Access Centres and 78 Computer Literacy Classes. With a high speed broadband technology on the road, Community Broadband Centre (CBC) and Community Broadband Library (CBL) have been introduced in some selected areas in the country. The Internet access in CBC and CBL is supported with broadband technology, fulfilling the government's target to reduce digital divide in the nation with the provision of better Internet service and quality especially in the rural areas. Currently, there are $174 \mathrm{CBCs}$ and $105 \mathrm{CBLs}$ in Malaysia as of June 2009, and these figures are expected to increase to 400 CBCs and 205 CBLs by the end of 2010 (Jailani, 2009).

One issue in operating telecenter is its sustainability. This is associated with TC's capability to run independently in terms of financial, administration, technical support and community acceptance and support. In relation with financial sustainability, the issue of fund always emerges as the centre of discussion. In most cases, TC is sponsored with an initial funding to start the operation. After a termination of the fund, TC operates on its own and this creates disappointment and failure (Proenza, 2001). From an economics point of view, if the revenue inflow of a TC does not cover expenses and generate a surplus, it will slow down its operation and eventually be 
forced to shut down. This is coined with financial viability. On the other hand, if TC does not generate sufficient income to cover operation and maintenance costs; or termed as operational viability, TC may have to shut down at an early period (Proenza, 2001). Thus, financial sustainability is assumed to have big influence in operating and managing TCs. The lesson learned from previous TCs implementation implies that proper monitoring mechanism is needed to ensure sustainability of TCs (Zulkhairi et al., 2008b).

Uncertainty about how to finance telecentres is hindering their spread and slowing down the delivery of the benefits that they are capable of delivering to even the poorest sections of society. A study therefore was conducted to identify and understand several related issues of financial sustainability in TC in Malaysia. The issues include sponsorship, costs, income, and financial sufficiency. At the end, strategies for financial sustainability and collaboration are recommended as a guideline to increase TCs sustainability in the future.

\section{Literature Review}

The implementation of TC in Malaysia has been well accepted by local communities (Mohd Nizam, 2005a; Mohd Nizam, 2005b). Managing TC, however, is challenged by some limitation such as improper physical environment, inadequate maintenance and repair, too little publicity, insufficient IT training (Noor Bathi, 2005), not enough ICT resources (Wan Rozaini et. al, 2007), a limited number of administrative staff (Hazita et. al, 2007). It is quite merciless especially with the issues of community relevance, community partnerships and participation, government policy, TC's objectives, and business planning, and most of all the issue of sustainability (Roman \& Colle, 2002).

Telecentre sustainability means more than financial sustainability, and telecentre financial sustainability means more than self-financing. Incentives for telecentres to generate revenues are helpful in contributing to overall sustainability. But it is a mistake to write off telecentres that are able to induce locally relevant development but do not generate sufficient revenue to cover their costs (Harris, 2007).

In approaching the issue of sustainability, telecentres face the question of how they can generate income yet serve those in the community who cannot afford to pay for "public goods" kinds of services (like access to health information). Some centres use the income from user fees and other income services to make public goods affordable or free (Colle, 2000).

\section{Methodology}

The study focused on TCs in four regions of Malaysia Peninsular (northern, central, southern and eastern). Sampling was done based on a population comprising of TCs implemented by state governments, non-governmental organizations (NGOs), and private sectors. The population list is based on Internet searches, list from the K-Economy Section, Economics Planning Unit (EPU) of the Prime Minister's Department, state government offices, as well as telephone calls to NGOs and private sector TCs. A total of 132 TCs, which is a part of the 1945 TCs registered under the EPU list in addition to a few TCs which are not in the EPU list, have been identified for this study.

The data collection sites were divided into four regions: Northern Region (Perlis, Kedah, Penang, Perak), Central Region (Selangor, Wilayah Persekutuan, Negeri Sembilan), Southern Region (Malacca, Johor), and Eastern Region (Kelantan, Terengganu, Pahang). Based on the sampling used, questionnaires were distributed to TCs' operators through mail or hand-delivered while visiting the TCs. Data collection process was completed in three weeks. A descriptive analysis and statistical techniques were employed in the study. Table I shows the distribution of questionnaire according to the regions and methods of distributions.

The questionnaires were designed into several sections. Apart from telecenter's profile, there are sections of telecentre community's profile, community involvement, and telecentre's sustainability capabilities. This paper focuses on the results and discussion on telecentre financial sustainability capabilities, which include sponsorship and fund, operating and maintenance costs, additional income, and financial sufficiency and problems.

\section{Findings}

Out of 132 TCs selected for the study, only $60(45 \%)$ have responded. From these numbers, 45 are state-based TCs, 5 are NGO-based TCs and 10 are private TCs. From 1314 questionnaires sent to users and community, only $540(41.9 \%)$ responses have returned. The result shows that most of the TCs have been established since 2005 . A total of $56 \%$ of state-based TCs, $60 \%$ of NGOs-based TCs and $55.6 \%$ of private TCs have started their operation since 2005. Based on this statistic, most of them are considered new and still at the early stage of their operations. At this infant stage, they merely focus on providing basic ICT services and Internet access without any cost to the public. The results pertaining to financial aspects of the TCs surveyed are given in the following section. 


\subsection{Sponsorship}

Sponsorship are received either in monetary or non- monetary form. Whilst money is crucial to start-up TCs, long term sustainability requires a combination of monetary and non-monetary form. The finding shows that TCs receive sponsorship from different sources including the federal government, state government, NGOs, private sector and multinational companies (MNCs), individuals, and Institutions of Higher Learning. The fund from the federal and state government is for computers and training, infrastructure and office equipment. The NGOs, on the other hand, provide computers and training while Institutions of higher learning (IHLs) provide trainers for workshops, training and academic advice. Non-financial sponsorship includes volunteers, advice, expertise, collaboration and leadership.

In overall, the federal government of Malaysia had contributed largely to the operation of TCs. The study shows that $19.14 \%$ of state-based TCs and NGO-based TCs $(80 \%)$ are financially supported by the federal government. For the private-owned TCs, the financial supports often come from financial institutions (33.33\%).

\subsection{Funds}

The study found that TCs received different amounts of funds from different sponsors (Table 2). The main source of fund for state-based TCs is the state government who has sponsored from RM8000 to RM63000. As shown in the table, NGO-based TCs has obtained an amount of RM2.5 millions from the federal government. This is considered as the highest amount compared to those received by the state-based and private TCs. For private TCs, most of the funds come from the state government and private firms with a maximum of RM60000.

\subsection{Costs}

The study shows that the costs incurred monthly at state-based TCs, NGO-based TCs and private TCs are staff salary, the cost of site and building (rental), utilities, computer hardware and related applications, training and other miscellaneous expenses (Table 3). All TCs agree that most of the expenses go for staff salary, water supply and electricity, and telecommunication.

The amount paid for staff salary varies among the three types of TCs. It starts from RM400 (the lowest) up to RM30000 (the highest). About 20\% of NGOs-based TCs pays RM30000 for the salary, while $60 \%$ of private TCs use about RM1650 to RM8500. A total of 31\% of state-based TCs spent about RM400 to RM15000 to pay for the workers' salary. In terms of water and electricity, the maximum amount spent per month is RM2000 and the minimum is RM30 in general. Thirteen state-based TCs (29\%) reported that their utility bills range from RM 30 to RM 2000 per month. Six private TCs (60\%) allocate RM 250 to RM 1000 while $40 \%$ of NGO-based TCs pay between RM 50 to RM 1500. Similar patterns occur in the expenses of telecommunication. Ten state-based TCs (22\%) reported that Internet and telephone expenses are between RM60 - 2500, whereas the private TCs expenditure is between RM 150 to RM 700.

In some cases, the premise use to run telecentre is rented and paid monthly. Generally, the rental ranges from RM 150 to RM 1400. As identified in Table 3, the lowest rental for state-based TCs is RM 250 while the most expensive is RM 14000 per month. The range of the rental reported by NGO-based TCs is from RM150 to RM 5000 while for the private TCs are from RM400 to RM1500.

\subsection{Additional income}

Apart from receiving funding from governmental and private agencies, TCs have resorted to other means to secure more funds, for instance from membership fees, provision of connectivity services (telephone, fax and Internet), office services (photocopy, scanning, and audio video), business services and educational services.

A total of $36 \%$ of state-based TCs have additional income generated from membership fees and connectivity services, while $34 \%$ of TCs acquire from office services. For most NGO-based TCs $(60 \%)$, the additional income is mainly acquired from provision of office services, for instance photocopy service. Though very minimal, the additional income for $40 \%$ of the TCs comes from community services, volunteer and community support. Other sources of income for this type of TCs are from connectivity services, educational services and sales. For private TCs, $66.66 \%$ of them reported that their additional income is mostly generated from office services and educational services, while $50 \%$ of the similar TCs obtain from business services, connectivity and sales.

\subsection{Financial sufficiency and problems}

The finding of the study highlights that only $21.27 \%$ of state-based TCs agree that the fund they receive from the sponsor and the additional income generated is sufficient to support their operation. A similar opinion is observed from both private TCs $(20 \%)$ and NGO-based TCs (33.3\%). It can be further presumed that more than $75 \%$ of all TCs are currently operating under tight cash budget. Among the financial related problems 
experienced by TCs are insufficient fund to maintain TCs as well as upgrading hardware and software, and high cost related to the provision of higher speed data connectivity. Due to financial scarcity, a few TCs have difficulties to pay salary to operators, while broken computers are left idle without repair. This problem explains why some of TCs that have been listed for the study were found closed or operated under a few limitations.

\section{Conclusion and recommendations}

All TCs receive certain amount of money from several sources to assist them in sustaining operations and services. Expenditures are made every month to pay for staff, building, utilities, computer hardware and software, training and other miscellaneous expenses. TCs also make an extra income by generating number of activities such as provision of connectivity services (telephone, fax and Internet), office services (photocopy, scanning, and audio video), business services and educational services.

The majority of TCs are currently operating under tight cash budget. Financial support is critical in order to continue giving services to communities. With an effective financial planning and monitoring, supported with good management and strong support from local community and neighborhood, there is a possibility that TCs could operate independently in the future.

In view of the actions to be taken by the government to stop funding of the government-operated TCs by 2010 , there is a need to formulate new strategies to self-sustain the TC's operation. This study recommends five strategies to be implemented at TCs to encourage financial sustainability even with the absence of any sponsorship. The idea behind these strategies is win-win situation. Fig. 1 shows the strategies together with the related entity or entities.

The first strategy proposed is regarding collaboration between TCs and NGOs and private companies. As shown in Fig. 1, TCs can be financially sustained through non-government organizations (NGOs) and other private entity to capitalise on the latter's corporate social responsibility. Varieties of programs such as training can be taken up to ensure continuity of TCs services.

The second strategy concerns with the idea of turning TCs into a social entrepreneur, for instance provide services that meet the TC's obligation to society in return for the community's contribution. In this circumstance, the authority to manage and own TC can be given to individuals who will run TCs as usual, and at the same time provide service to communities through another business to generate income to support TCs sustainability. Minimum subsidy schemes could be established by private agencies or firms to encourage and support individuals in the development of telecommunications and telecenter infrastructure. In this scenario, the subsidized schemes stimulate a form of telecenter franchising such as those being implemented by the Grameen Telecom ((http://www.citechco.net/grameen/telecom/). The infrastructure development is undertaken by a large firm, but the management of TCs is under local entrepreneurs.

The third strategy is about strategic alliances between TCs and local entities such as mosques, local community associations and committees, sundry shops and retailers. Different programs can be created to generate income for the benefits of both sides. Another strategy, the fourth, is to provide incentives such as discounts to community members for using certain services at TCs. The final strategy is to set up a network of TCs all over the country and to devise membership schemes to allow individuals to enjoy wider accessibility and facilities at minimal cost.

Findings from the study show that financial support is critical to continuously provide ICT and Internet services to public communities. High investment is needed not only to operate TCs but also to maintain the centers. Strategies that focused on the collaboration among entities namely government and non-government agencies, TCs operators, local communities bodies, and TC users are recommended to sustain TCs in the long run.

\section{References}

Colle, R. (2000). Communication Shops and Telecenters in Developing Nations, in Gurstein, M. (ed), Community Informatics: Enabling Communities with Information and Communications Technologies, Idea Group Press, Hershey, PA.

Harris, R. (2007). Telecentre Sustainability- Financing ICTs for the poor. APDIP e-Note 15 / 2007. [Online] Available: http://www.apdip.net/apdipenote/15.pdf (March 18, 2010).

Hazita A., Siti Hanim S., Jamilah M., Tg Nor Rizan T.M.M., Noraza A. Z., Kalthum I., Norwati M.. Y., and Zaini A. (2007). Peranan Pusat e-komuniti terhadap Pembangunan Kemahiran: eLiterasi di Kalangan Warga Belia Luar Bandar. E-Community Research Center Colloquium, Universiti Kebangsaan Malaysia, Malaysia. [In Malay]. 
Jailani J. (2009). An Interview between ITU-UUM, CoeRI, and SKMM at Cyber Jaya on 9th June.

Mohd Nizam O. (2005a). Dasar Perlaksanaan Inisiatif 'Internet Desa': Cabaran dan Implikasi dalam mengurangkan jaringan digital di Malaysia. In a workshop 'Membudayakan Masyarakat Jaringan: Cabaran dan Batasan', Universiti Kebangsaan Malaysia, Malaysia. [In Malay].

Mohd Nizam O. (2005b). Information and Communication Technology Policies in Malaysia: Analysis on Government Measures to Minimize the Digital Divide. National E-Community Seminar 2005, Universiti Kebangsaan Malaysia.

Noor Bathi B. (2005). Draft Rural ICT Guidebook - Based on Malaysian Experience, presented at Regional Meeting on Effective Design and Delivery of Rural Community ICT Services by UNESCAP/INTAN, 2005, INTAN Bukit Kiara, Kuala Lumpur, Malaysia.

Proenza. F. J. (2001). Telecenter Sustainability-Myths and Opportunities. In a Special issue on Telecenters of the Journal of Development Communication, December.

Roman, R. and Colle, R. D. (2002). Themes and Issues in Telecentre Sustainability. Working Papers Series, Paper no. 10. Institute for Development Policy and Management, University of Manchester, Precinct Centre, Manchester, UK.

Songan, P., Khairuddin A. H., Yeo, A., Gnaniah, J., and Hushairi Z. (2004). Community Informatics: Challenges in Bridging the Digital Divide. In Khalid, H.M., Helander, M.G. and Yeo, A.W. (Ed.), Work with Computing System 2004. Kuala Lumpur: Damai Science.

UNESCAP (2006). Guidebook on Developing Community e-Centres in Rural Areas: Based on the Malaysian Experience. United Nations Economic and Social Commission for Asia and the Pacific.

Wan Rozaini S. O., Zahurin M. A., Huda I., Nor Iadah Y., and Nafishah O. (2007). Ke Arah Memperkasakan Komuniti Luar Bandar: Penilaian Situasi Semasa Pusat Internet Desa (PID). E-Community Research Center Colloquium, 2007. Universiti Kebangsaan Malaysia, Malaysia. [In Malay].

Table 1. Distribution of TCs and Questionnaire

\begin{tabular}{|l|c|c|c|c|}
\hline Region & Total TCs & $\begin{array}{c}\text { TCs } \\
\text { Visited }\end{array}$ & $\begin{array}{c}\text { TCs } \\
\text { via mail }\end{array}$ & No. of Questionnaire Distributed \\
\hline North & 44 & 4 & 40 & 453 \\
\hline Central & 33 & 6 & 27 & 311 \\
\hline South & 29 & 9 & 20 & 290 \\
\hline East & 26 & 8 & 18 & 260 \\
\hline Total & 132 & 27 & 105 & 1314 \\
\hline
\end{tabular}

Table 2. Amounts of Funds

\begin{tabular}{|l|l|}
\hline TCs & Supporting Agencies and Amounts Funded (RM) \\
\hline State TCs & $\begin{array}{l}\text { State Government- RM 8000 to RM 63000 } \\
\text { Federal government- RM7000 } \\
\text { Individual, others - RM1800 to RM2000 }\end{array}$ \\
\hline NGO TCs & $\begin{array}{l}\text { Federal government RM2.5 million } \\
\text { Private sector- RM1 million } \\
\text { Individual, surrounding community- RM50000 each }\end{array}$ \\
\hline Private TCs & $\begin{array}{l}\text { Federal government- RM55000 } \\
\text { Private firms- RM60000 } \\
\text { State government, financial institutions - RM1500 to RM24000 }\end{array}$ \\
\hline
\end{tabular}


Table 3. Range of Monthly Costs for TCs

\begin{tabular}{|c|c|c|c|}
\hline \multirow{2}{*}{ Item } & \multicolumn{3}{|c|}{ Range from lowest to highest according to types of TCs (RM) } \\
\hline & State-based TC & NGO-based TCs & Private TCs \\
\hline Site \& Building (Rent) & $250-1400$ & $150-5000$ & $400-1500$ \\
\hline Computer/hardware/ Software & $200-3000$ & $100-2500$ & $100-300$ \\
\hline Training/Module & $20-1500$ & 5000 & $100-1000$ \\
\hline Telecommunication & $60-2500$ & - & $150-700$ \\
\hline Security & $100-150$ & - & $50-500$ \\
\hline $\begin{array}{l}\text { Water Supply } \\
\text { / Electricity }\end{array}$ & $30-2000$ & $50-1500$ & $250-1000$ \\
\hline Furniture & $200-10000$ & 1000 & $200-500$ \\
\hline Promotion & $10-1000$ & 1000 & $100-1000$ \\
\hline Staff Salary & $400-15000$ & 30000 & $1650-8500$ \\
\hline
\end{tabular}

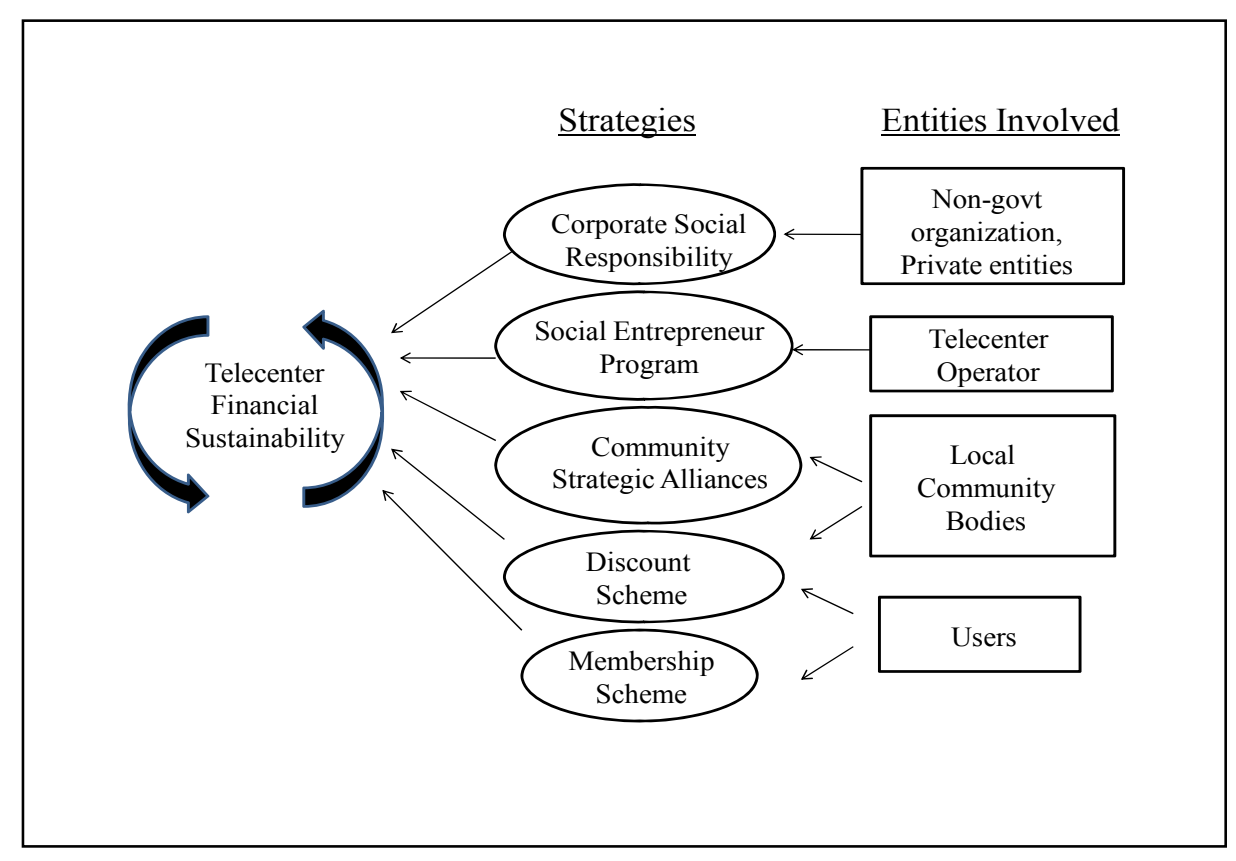

Figure 1. Financial Sustainability Strategies 